Adam Badrulhisham \& Khadijah, "Konsep Roh Suci menurut Islam dan Kristian," Afkār Vol. 20 Issue 1 (2018): 85-108

\title{
KONSEP ROH SUCI MENURUT ISLAM DAN KRISTIAN
}

THE CONCEPT OF HOLY SPIRIT

IN ISLAM AND CHRISTIAN

\section{Adam Badhrulhisham* \& Khadijah Mohd} Khambali@Hambali**

*University College of Islam Melaka. 78200. Melaka. Malaysia.

${ }^{* *}$ Department of `Aqidah \& Islamic Thought. Academy of Islamic Studies. University of Malaya. 50603. Kuala Lumpur. Malaysia.

Email: *adambadhrul@kuim.edu.my

DOI: https://doi.org/10.22452/afkar.vol20no1.3

\section{Khulasah}

Rūh al-Qudus atau Holy Spirit membawa pengertian yang sama dari sudut bahasa iaitu roh suci. Konsep ini wujud dalam agama Islam dan Kristian selaku agama yang mempunyai hubungan yang rapat dari sudut sejarah dan kepercayaan. Namun terdapat perbezaan besar antara konsep ini menurut kedua-dua agama yang mengakibatkan kekeliruan dan salah faham yang membawa impak yang besar dalam kehidupan beragama. Artikel ini bertujuan menjelaskan perbezaan ini dengan menggunakan metode kualitatif perbandingan. Secara umumnya dapat dilihat kedua konsep ini mempunyai perbezaan yang amat ketara iaitu dalam konsep ketuhanan walaupun berkongsi istilah yang serupa. Rūh al-Qudus dalam Islam merujuk kepada malaikat Jibril manakala Holy Spirit pula merujuk kepada zat Tuhan. Hal ini perlu dijelaskan bagi mengelakkan sebarang kekeliruan dan salah faham dalam konteks kehidupan beragama.

Kata kunci: Roh suci; rūh al-Qudus, Holy Spirit, Jibril, Islam dan Kristian. 


\begin{abstract}
In the context of language, Rūh al-Qudus or Holy Spirit carries the same meaning. This concept exists in Islam and Christianity as the religions that have a distinct relationship from the context of history and belief. But there is a big difference between the concepts that brought up confusion and misunderstanding. It also has a direct impact in interfaith life. This article aims on explaining the differences using comparative qualitative methods. In general, it can be seen that these two concepts have a very significant difference, namely, in divine concepts, even sharing similar terms. Rūh al-Qudus in Islam refers to the angel Gabriel while the Holy Spirit refers to the substance of God. This should be explained to avoid any confusion and misunderstanding in the context of interfaith relation.
\end{abstract}

Keywords: Rūh al-Qudus; Holy Spirit; Jibril; Islam; Christianity.

\title{
Pendahuluan
}

Islam sebagai agama terakhir dalam kalangan agama samawi sering dikatakan menerima pengaruh agama terdahulu (Yahudi dan Kristian). Kesempatan Nabi Muhammad SAW untuk berdagang di sekitar Tanah Arab menjadi alasan dakwaan bahawa baginda menerima pengaruh ahli Kitab dalam intipati agama Islam. ${ }^{1}$ Hal ini disebabkan Islam dan Kristian (dan Yahudi) sememangnya berkongsi banyak perkara yang sama sekalipun hakikat dan intipatinya berbeza.

Antara yang menjadi titik persamaan ialah berkenaan roh suci. Roh suci atau Rūh al-Qudus ataupun Holy Spirit merupakan konsep yang wujud dalam agama Islam dan Kristian. Konsep ini menjadi asas kepada pembentukan kepercayaan agama Kristian kerana ia dianggap sebagai

\footnotetext{
${ }^{1}$ Judy Tao Shih-Ching, "The Holy Spirit in the Qur'an: An Assessment From a Christian Perspective", (Disertasi Sarjana, University of Stellenbosch, South Africa, 2006).
} 
salah satu daripada oknum tuhan yang membentuk fahaman trinity. Begitu juga dengan konsep Rūh al-Qudus dalam Islam, meskipun berlainan dengan konsep agama Kristian, ia mempunyai peranan yang cukup penting sebagai malaikat yang membawa risalah kepada para nabi sebagai panduan untuk umat manusia. Holy Spirit pula secara asasnya ialah roh tuhan yang memandu penganut Kristian seperti mana ia memandu Jesus Christ dalam misinya di dunia. $^{2}$

Uniknya, kedua-dua agama menggunakan penamaan yang sama terhadap dua entiti yang diertikan dengan cukup berbeza. Perkara ini berkemungkinan mencetuskan kekeliruan dalam menanggapi hakikat roh suci menurut satu-satu agama seperti mana yang pernah berlaku pada tahun 1997 di Indonesia apabila seorang wanita Muslimah mendakwa beliau didampingi oleh Jibril. ${ }^{3}$ Dalam kes ini dapat dilihat pemahaman roh suci menurut Kristian telah digunapakai dalam kepercayaan seorang Muslim di Indonesia. Oleh itu penulisan ini cuba mengupas perbandingan konsep roh suci daripada perspektif keduadua agama iaitu Islam dan Kristian.

\section{Rūh al-Qudus dalam Islam}

\section{i. Definisi $R \bar{u} h$}

Menurut Ibn Fāris, kalimah rūh berasal daripada al-rīh (الريح) yang merujuk kepada angin. Menurut beliau, huruf $y \bar{a}$ (ي) ditukarkan daripada waw (و) untuk disesuaikan dengan huruf $r \bar{a}(\jmath)$ yang berbaris bawah. ${ }^{4}$ Beliau juga menyatakan kalimah rūh merujuk kepada nafas manusia.

${ }^{2}$ Marry Ellen Pereira, "The Holy Spirit in the Gospel of John", Leaven: Vol. 12: (Iss. 3, 2004), article 5.

${ }^{3}$ Fatwa Dewan Pimpinan Majlis Ulama Indonesia tentang Malaikat Jibril Mendatangi Manusia, dicapai 17 November 2017, http://mui.or.id/wp-content/uploads/2014/05/09.-Fatwa-DewanPimpinan-MUI-Tentang-Malaikat-Jibril-Mendamp.pdf.

${ }^{4}$ Abū al-Husayn Aḥmad Ibn Fāris, Mu jam Miqyās al-Lughah, jil. 2 (Damsyik: Dār al-Fikr, 1979), 454. 
Ibn Manẓūr menyetujui pandangan ini dengan berpendapat (روح), jama'nya (أرواح) berasal daripada kalimah (الريح) yang bermaksud angin, dan apabila digandingkan dengan manusia ianya bermaksud nafas. Ianya sebagai nafas yang dihirup oleh manusia yang mengalir dalam jasad manusia sehingga membuatkannya hidup. ${ }^{5}$ Al-Rāghib al-Asfahānī pula menyatakan rūh ialah salah satu nama bagi nafas seperti mana nama-nama yang diberikan kepada objekobjek yang berbeza dalam kelompok yang sama. ${ }^{6}$

\section{ii. Rūh dalam al-Qur'an}

Walau bagaimanapun kalimah rūh dalam al-Qur'an tidak terhad kepada angin atau nafas yang membuatkan seseorang itu hidup semata-mata. Ia boleh membawa maksud yang pelbagai antaranya:

1. Makhluk ciptaan Allah yang tidak diketahui hakikatnya oleh manusia. ${ }^{7}$ Keadaan ini merujuk kepada kalimah roh dalam ayat surah al-Nisa':

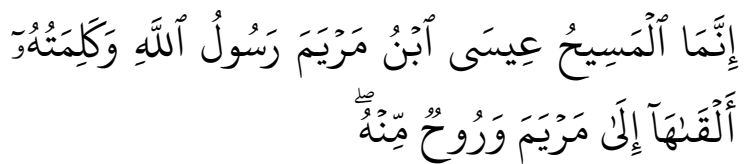

Terjemahan: "Sesungguhnya al-Masih Isa Ibni Maryam itu hanya seorang pesuruh Allah dan kalimah Allah yang telah disampaikanNya kepada Maryam, dan (ia juga tiupan) roh daripadanya."

\section{Al-Nisā' (4): 171}

2. Wahyu, kenabian, al-Qur'an dan perintah kerana kesemua ini dapat menghidupkan jiwa yang kufur

\footnotetext{
${ }^{5}$ Ibn Manzūr, Abū Faḍl Jamāl al-Dīn Muhammad bin Mukram, Lisān $a l$-'Arab, jil. 5, cet. 3 (Beirut: Dār Ihyē̄' al-Turāth al-'Arabī, 2012), 356.

${ }^{6}$ Al-Rāghib al-Așfahānī, Mufradāt Alfāz al-Qur'ān (Damsyik: Dār alQalam, 2009), 369.

${ }^{7}$ Ibn Manzūr , Lisān al- 'Arab, 356.
} 
sepertimana roh yang menghidupkan jasad. Kalimah rūh dalam makna ini dapat dilihat dalam ayat:

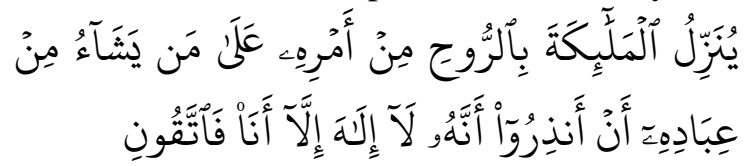

Terjemahan: "Dia menurunkan malaikat membawa wahyu dengan perintahNya kepada sesiapa yang dikehendakiNya dari hambahambaNya (yang layak menjadi Rasul); (lalu ia berfirman kepada rasul-rasul): "Hendaklah kamu menegaskan kepada umat manusia bahawa tiada Tuhan melainkan Aku. Oleh itu, bertaqwalah kamu kepadaku."

Al-Nahl (16): 2

3. Kalimah rūh ada ketikanya membawa maksud rahmat:

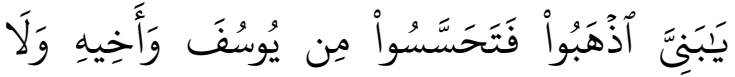

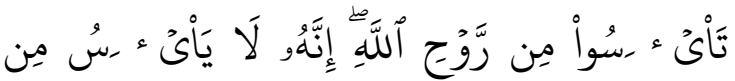



Terjemahan "Dan janganlah kamu berputus asa dari rahmat serta pertolongan Allah. Sesungguhnya tidak berputus asa dari rahmat dan pertolongan Allah itu melainkan kaum yang kafir."

$$
\text { Yūsuf (12): } 87
$$

4. Membawa maksud malaikat, khususnya malaikat Jibril. Ini dapat dilihat dalam firman Allah SWT:

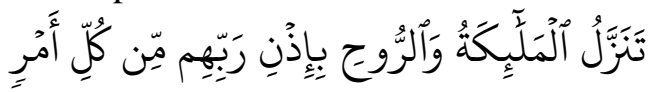

Terjemahan: "Pada malam itu, turun malaikat dan Jibril dengan izin Tuhan mereka, kerana 
membawa segala perkara (yang ditakdirkan berlakunya pada tahun yang berikut)."

Al-Qadr (97):5

\section{iii. Rüh al-Qudus dalam al-Qur'an}

Rüh al-Qudus secara literalnya bermaksud roh suci atau holy spirit. Kalimah Rūh al-Qudus disebutkan dalam alQuran secara spesifik sebanyak 4 kali iaitu dalam surah alBaqarah, surah al-Nisā', surah al-Mā'idah dan surah alNahl. ${ }^{8}$. Dalam surah al-Baqarah dinyatakan:

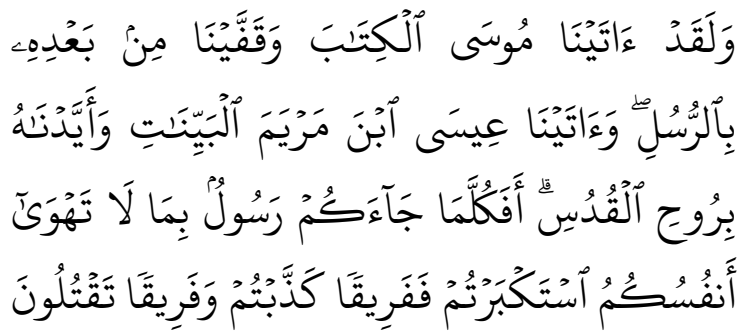

Terjemahan: "Dan sesungguhnya Kami telah memberikan kepada Nabi Musa kitab Taurat, dan Kami iringi kemudian daripadanya dengan beberapa orang rasul, dan Kami berikan kepada Nabi Isa ibni Maryam beberapa mukjizat serta Kami teguhkan kebenarannya dengan $R \bar{u} h$ alQudus (Jibril), maka patutkah, tiap-tiap kali datang kepada kamu seorang rasul membawa sesuatu (kebenaran) yang tidak disukai oleh hawa nafsu kamu, kamu (dengan) sombong takbur (menolaknya), sehingga sebahagian dari rasul-rasul itu kamu dustakan, dan sebahagian yang lain pula kamu membunuhnya?"

$$
\text { Al-Baqarah (2): } 87
$$

Imam Fakhr al-Dīn al-Rāzì dalam tafsirnya Tafsīr alKabīr menyatakan terdapat beberapa pendapat mengenai

${ }^{8}$ Muhammad Fu'ād 'Abd al-Bāqī, al-Mu 'jam al-Mufahris li Alfāz alQur'ān al-Karīm (Kaherah: Dār al-Hadīth, 1996), 326. 
perkataan Rūh al-Qudus dalam ayat ini. Pertama, ia dimaksudkan dengan malaikat Jibril 'alayh al-salām (AS). Kedua, ianya merujuk kepada kitab Injil yang diturunkan kepada Nabi Isa AS. Ketiga, ianya adalah kalimah yang digunakan oleh Nabi Isa AS untuk menghidupkan orang yang mati sebagai salah satu mukjizat baginda. Dan keempat, ianya merujuk kepada roh yang ditiupkan ke dalam tubuh baginda (Nabi Isa) dan dipadankan dengan kalimah al-quds (suci) sebagai kemuliaan dan penghormatan kepada baginda. Pendapat terakhir ini menjadi pilihan beberapa ulama' seperti al-Baghaw $\overline{1}^{9}$ dan al-Burūsawīi ${ }^{10}$.

Al-Suyūṭ̂̄ juga menukilkan riwayat yang menyokong pendapat ini sebagai pendapat pertama beliau dalam kitabnya al-Durr al-Manthūr fì al-Tafsīr bi al-Ma'thūr. ${ }^{11}$ Begitu juga dengan al-Zamakhsharī, beliau memilih pandangan ini sebagai pendapat pertama dalam tafsirnya. Menurut beliau perkataan 'suci' menunjukkan keakraban dan kemuliaan Nabi Isa AS di sisi Allah. ${ }^{12}$

Walau bagaimanapun kebanyakan ulama mentarjihkan pendapat yang pertama termasuk al-Rāzì. Ini adalah berpandukan beberapa sebab: Pertama, berdasarkan kesesuaian konteks ayat. Dalam ayat tersebut, disebutkan Rūh al-Qudus sebagai yang 'meneguhkan kebenarannya'


bantuan dan pertolongan yang sudah pastinya lebih sesuai

${ }^{9}$ Abū Muhammad al-Husayn bin Mas ‘ūd al-Baghawī, Ma 'ālim al-Tanzīl (Riyadh: Dār Țayyibah, 1988), 120.

${ }^{10}$ Ismā'īl Haqqī al-Burūsawī, Tafsīr Rūḥ al-Bayān (Dār 'Uthmaniyyah, t.t), 177.

${ }^{11}$ Jalāl al-Dīn al-Suyūți, al-Durr al-Manthūr fì al-Tafsīr bi al-Ma'thūr, jil. 1 (Kaherah: Markaz Hajr li al-Buhūth wa al-Dirāsāt al-'Arabiyyah wa al-Islāmiyyah, 2003), 459.

12 Abū al-Qāsim Maḥmūd bin 'Umar al-Zamakhsharī, al-Kashshāf 'an Haqū 'iq al-Tanzīl wa 'Uyūn al-Aqāwil fi Wujūh al-Ta'wil (Beirut: Dār al-Ma'rifah, 2009), 85. 
dengan pemaknaannya sebagai Jibril AS. ${ }^{13}$ Kedua, hakikat kejadian Jibril AS yang diciptakan daripada cahaya yang bersifat rohani. Oleh itu penggunaan kalimah rüh lebih tepat merujuk kepadanya berbanding manusia mahu pun Injil yang merupakan sesuatu yang bersifat fizikal. Perkara ini diperkuatkan lagi dengan penggunaan $R \bar{u} h$ al-Qudus dalam ayat di dalam surah al-Nahl:

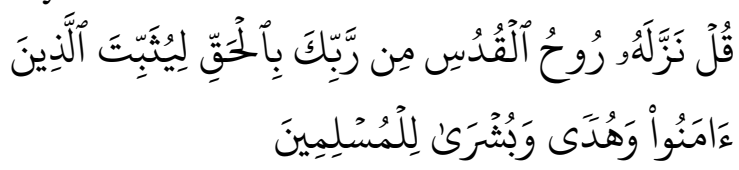

Maksudnya: "Katakanlah (wahai Muhammad): al-Qur'an itu diturunkan oleh Rūh al-Quds (Jibril) dari Tuhanmu dengan cara yang sungguh layak dan berhikmah, untuk meneguhkan iman orang-orang yang beriman, dan untuk menjadi hidayah petunjuk serta berita yang mengembirakan bagi orang-orang Islam."

\section{Al-Nahl (16): 102}

Ketiga, dalam beberapa ayat lain, penggunaan kalimah rūh merujuk kepada Jibril (surah al-Shu'ara' dan surah Maryam). Persandaran kalimah al-quds (suci) dalam ayat pula adalah kerana hakikat Jibril yang sentiasa suci daripada dosa. ${ }^{14}$ Penggunaan kalimah rūh (nafas yang menghidupkan) juga bertepatan dengan hakikat tugas Jibril kerana Jibril diamanahkan untuk membawa wahyu yang menghidupkan hati manusia yang mati. ${ }^{15}$ Oleh itu Rüh alQudus dalam al-Qur'an dilihat lebih tepat sebagai merujuk kepada malaikat Jibril.

13 Fakhr al-Dīn al-Rāzī, Tafsīr al-Kabīr wa Mafātiḥ al-Ghayb, jil. 3 (Beirut: Dār al-Fikr, 1981), 190-191.

${ }^{14}$ Al-Zamakhsharī, al-Kashshāf, 584.

${ }^{15}$ Ibn Manzūur, Lisān al- 'Arab, 463. 


\section{iv. Malaikat Jibril dalam Islam}

Rūh al-Qudus menurut Islam merujuk kepada Jibril iaitu salah satu malaikat yang diciptakan. Malaikat adalah makhluk ciptaan Allah SWT daripada cahaya yang berjisim halus, tinggal di langit dan boleh menyerupai pelbagai bentuk. ${ }^{16}$ Sebagai makhluk Allah, semestinya ia mempunyai kewajipan dan tertakluk kepada perintah Allah SWT.

Jibril dianggap sebagai makhluk istimewa yang menduduki darjat yang sangat mulia di sisi Allah SWT. Jibril merupakan salah satu daripada Ruasā' al-Malāikah (ketua malaikat) yang empat. Mereka juga digelar sebagai al-'Uzamā' al-Arba'ah (empat malaikat yang agung). Mereka ialah Jibril, Mikail, Israfil dan malaikat maut. ${ }^{17}$ Dalam sebuah hadis ada disebutkan bahawa Rasulullah SAW bersabda, "Makhluk yang paling akrab dengan Allah SWT ialah Jibril, Mikail dan Israfil." Dalam riwayat lain apabila ditanyakan kepada Jibril siapakah makhluk yang paling hampir di sisi Allah SWT Jibril menjawab "Makhluk yang paling hampir ialah Jibril, Mikail, Israfil dan malaikat maut."18

Kalimah Jibrīl (جبريل) diulang sebut secara literal dalam al-Quran sebanyak tiga kali iaitu dua kali dalam surah al-Baqarah dan satu kali dalam surah al-Tahrīm. ${ }^{19}$ Perkataan Jibrīl adalah nama bukan arab (a jami) yang bersifat tidak berubah (mamnū' min al-sarf) disebabkan ianya kata nama khas. Al-Alūsī menyatakan terdapat tiga belas cara sebutan Jibril iaitu Jibrīl (جِبريل), Jabrīl (جَبريل),

\footnotetext{
${ }^{16}$ Al-Rāzī, al-Kabìr, 175.

${ }^{17}$ Malaikat maut tidak disebutkan secara literal namanya dalam al-Qurān dan Hadis sepertimana Jibril, Mikail dan Israfil. Namun begitu nama Izra'il terdapat dalam beberapa athār. Musțafā 'Āshūr, 'Ālam alMalāikah Asrāruh wa Khafāyāh (Kaherah: Maktabah al-Qur'ān, t.t), 31.

18 Al-Suyūṭī, al-Durr al-Manthūr 495.

${ }^{19}$ Muhammad Fu’ād `Abd al-Bāqī,al-Mu‘jam., entri 163.
} 


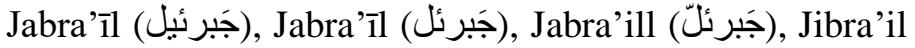



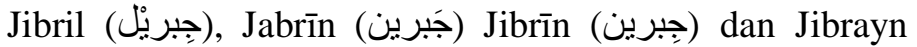
(جِبر اين)

Jibrail secara umumnya diterima sebagai bermaksud 'Abd Allāh iaitu hamba Allah. Ianya berasal daripada dua suku kata iaitu Jibr (جبر) dan îl (ئيل) yang bermaksud hamba Tuhan. Menurut al-Khāzin maksud Jibril sama dengan Mikail kerana dalam bahasa Suriani, Jibr (جبر) dan Mīk (ميك) bermakna hamba dan 11 (ئيل) bermakna Tuhan. ${ }^{21}$ Imam Jalal al-Dīn al-Suyūti menyatakan dalam riwayat lain dikhabarkan bahawa Jibril bermaksud `Abd Allāh, manakala Mikail bermaksud 'Ubayd Allāh. Manakala dalam riwayat lain dinyatakan bahawa Isrāfil pula bermaksud 'Abd al-Raḥmān. Ada juga riwayat yang menceritakan bahawa Jibril bermaksud khadam Allah SWT. Namun disepakati bahawa setiap kalimah yang bersambung dengan kalimah -îl membawa maksud hamba Allah. $^{22}$

Jibril mempunyai sifat-sifat keagungan seperti mempunyai kekuatan yang luarbiasa, ${ }^{23}$ rupa paras yang agung, ${ }^{24}$ ditaati di kalangan para penghuni langit dan bersifat amanah. ${ }^{25}$ Tugas utama Jibril adalah untuk menyampaikan wahyu daripada Allah kepada para rasul, ${ }^{26}$

20 Shihāb ad-Dīn al-Sayyid Maḥmūd al-Baghdādī al-Alūsī, Rūh alMa 'ānī fì Tafsìr al-Qur'ān al-Az̄ìm wa al-Sab'i al-Mathānī, jil. 1 (Beirut: Dār al-Fikr, 1994), 524.

${ }^{21}$ Alā' ad-Dīn 'Alī bin Muhammad bin Ibrāhīm al-Baghdādī al-Khāzin, Lubab at-Ta'wil fì Ma'ānì at-Tanzīl (Beirut: Dār al-Kutub al'Ilmiyyah 1995), 63.

${ }^{22}$ Al-Suyūțī, al-Durr al-Manthūr 484.

${ }^{23}$ Al-Najm 53: 5-6.

${ }^{24}$ Al-Najm 53: 6.

25 Al-Takwir 81: 21.

${ }^{26}$ Al-Baqarah 2: 97. 
di samping memimpin para malaikat dalam Perang Badar, ${ }^{27}$ menurunkan azab kepada pengingkar arahan Tuhan, ${ }^{28}$ berurusan dengan doa dan permintaan manusia ${ }^{29}$ dan lainlain. Meskipun disifatkan dengan pelbagai sifat keagungan, Islam menganggap Jibril termasuk dalam hamba Allah yang mempunyai kewajipan dan tanggungjawab terhadapNya. Ia sama sekali tidak mencapai darjat ketuhanan bahkan ia adalah makhluk yang sentiasa taat beribadah kepada Allah SWT dan akan dimatikan apabila sampai masanya kelak.

\section{Holy Spirit dalam Bible}

Holy Spirit secara literalnya bermaksud roh yang suci. Ianya merupakan salah satu entiti dalam konsep trinity yang diyakini oleh majoriti penganut Kristian. ${ }^{30}$ Perkembangan pemahaman konsep Holy Spirit dalam ajaran Kristian boleh dibahagikan kepada dua peringkat. Peringkat pertama ialah zaman Perjanjian Lama. Ketika ini Bani Israel tidak membezakan antara tuhan dengan roh tuhan. ${ }^{31}$ Mereka akan menggelar segala kuasa tuhan sebagai ruach dan segala perbuatan tuhan disandarkan kepada ruach. Perkataan ruach juga kadangkala dimaksudkan sebagai angin yang menciptakan (Genesis 8:1).

Pendek kata segala kuasa tuhan yang bukan sahaja mematikan dan memusnahkan malah menghidupkan akan

27 Āli 'Imrān 3: 123-126. Walaupun tidak dinyatakan secara jelas peranan Jibril dalam peristiwa, secara umumnya difahami bahawa Jibril berperanan sebagai pemimpin bala tentera malaikat. Abdul Hamid Kishk, The World of Angels (Dār al-Taqwā, t.t), 58.

${ }^{28}$ Hūd 11: 82-83.

${ }^{29}$ Al-Suyūṭi, al-Durr al-Manthūr, h. 487

${ }^{30}$ Jefferey E. Brower, "Understanding the Trinity", Logos: A Journal of Catholic Thought and Culture, jil. 8, (no. 1, 2005), 145, dicapai 17 November 2017. https://www3.nd.edu/ mrea/papers/Understanding\%20the\%20Trinit y.pdf .

31 Don Fleming, Bridgeway Bible Dictionary (Australia: Bridgeway Publications, 2004), entri: Holy spirit. 
disebut sebagai ruach. Namun, Tuhan menjanjikan bahawa akan tiba masa apabila semua tuhan akan melimpahkan roh tuhan ke atas hamba-hambaNya (Ezekial 36:27). Bani Israel ketika ini memahami bahawa roh tuhan yang dimaksudkan adalah satu entiti lain yang terasing daripada tuhan, bukan tuhan sendiri. ${ }^{32}$

Hanya selepas kedatangan Jesus pengertian Holy Spirit berkembang ke tahap seterusnya. Pada peringkat ini Jesus dikatakan memiliki Holy Spirit yang tidak terhad dalam jasadnya. Ketika zaman ini barulah difahami bahawa tuhan itu Tuhan di syurga, Jesus itu Tuhan di bumi dan Holy Spirit sebagai Tuhan yang datang daripada Tuhan dan tinggal dalam jasad Jesus (Isaiah 11:2). ${ }^{33}$ Pemahaman konsep Holy Spirit pada zaman ini berkembang menjadi satu entiti yang berbeza dari tuhan namun tidak boleh dipisahkan sama dengan Tuhan dan Jesus. Gabungan Tuhan, Jesus dan Holy Spirit inilah yang dikenali sebagai trinity.

Perbahasan mengenai Holy Spirit pernah dibincangkan dalam beberapa persidangan seperti di Alexanderia pada tahun $362 \mathrm{M}$ dan Rom pada tahun $375 \mathrm{M}$ dan akhirnya diputuskan dalam Persidangan Constantinople (381M) bahawa Holy Spirit adalah zat Tuhan yang membentuk trinity, bukannya makhluk. Keputusan ini dicapai atas beberapa hujah antaranya konsep Holy Spirit tidak pernah disebutkan secara jelas dalam teks suci bahawa ianya adalah makhluk tuhan dan Holy Spirit tidak menempati sebarang tempat berbeza dengan para rasul dan angels yang menempati tempat tertentu. ${ }^{34}$

\footnotetext{
${ }^{32}$ Ibid.

${ }^{33}$ Ibid.

${ }^{34}$ Philip Schaff, History of the Christian Church Volume III: Nicene and Post-Nicene Christianity. A.D. 311-600 (Michigan: Christian Classic Ethereal Library, t.t), 576.
} 
Holy Spirit disimbolkan dengan burung merpati (Matthew 3:16) sama ada secara literal atau perumpamaan, kerana merpati dianggap sebagai makhluk yang sangat tenteram, jinak dan bijaksana. ${ }^{35}$ Dalam Perjanjian Baru, Holy Spirit merujuk kepada manifestasi kuasa agung yakni tuhan (manifestation of divine power) yang dihantar kepada umat manusia untuk memahami hakikat Tuhan. ${ }^{36}$ Menurut V.E. Vines, Holy Spirit merujuk kepada sifat suci tuhan, salah satu daripada personaliti tuhan, kerja tuhan yang menaungi Jesus Christ dan juga sekalian penganut Kristian. Beliau menyebutkan:

"The subject of the "Holy Spirit" in the NT (New Testament) may be considered as to His divine attributes; His distinct Personality in the Godhead; His operation in connection with the Lord Jesus in His birth, His life, His baptism, His death; His operations in the world; in the church; His having been sent at Pentecost by the Father and by Christ; His operations in the individual believer; in local churches; His operations in the production of Holy Scripture; His work in the world, etc." ${ }^{37}$

Paul pula menggambarkan Holy Spirit sebagai suatu kesedaran atau kuasa yang tinggal dalam jasad seseorang yang berinteraksi dengan roh mereka dan kadangkala mampu berinteraksi dengan Tuhan (Rom 8: 25-27)..$^{38}$ Oleh itu dapat disimpulkan bahawa antara ciri utama Holy Spirit ialah ia menempati (indwelling) individu-individu tertentu

\footnotetext{
35 Matthew Henry's Commentary, https://www.biblegateway.com/passage/?search=Matthew $+3 \&$ versio $\mathrm{n}=\mathrm{NIV} \&$ resource $=$ matthew-henry

36 James R. Adair, Introducing Christianity (Abingdon: Routledge, 2008), 362.

37 V.E. Vines, Vine's Complete Expository Dictionary of Old and New Testament Words.

${ }^{38}$ Adair, Introducing Christianity, 363.
} 
untuk menghubungkan seseorang dengan Tuhan khusunya pada era Perjanjian Baru. ${ }^{39}$

\section{i. Fungsi Holy Spirit}

Secara umumnya Holy Spirit difahami sebagai roh Tuhan dan Jesus yang tidak dapat dipisahkan sama sekali. Walaupun Holy Spirit dianggap sebagai Christ, ianya dipercayai dianugerahkan kepada pengikut-pengikut Jesus selepas ketiadaannya di muka bumi. ${ }^{40}$ Holy Spirit dalam kepercayaan Kristian boleh dirumuskan mempunyai fungsi berikut:

1. Membantu pengikut Jesus menyebarkan ajaran Kristian: "Then Peter, filled with the Holy Spirit, said to them: "Rulers and elders of the people!" (Acts: 4:8)

2. Memberkati para pengikut dan menyelamatkan mereka (salvation): "And you also were included in Christ when you heard the message of truth, the gospel of your salvation. When you believed, you were marked in him with a seal, the promised Holy Spirit. Who is a deposit guaranteeing our inheritance until the redemption of those who are God's possession - to the praise of his glory." (Ephesians 1: 13-14)

3. Memandu mereka mengikut jalan Tuhan: "Those who belong to Christ Jesus have crucified the flesh with its passions and desires. Since we live by the Spirit, let us keep in step with the Spirit". (Galatians 5: 24-25)

4. Memandu para pengikut dalam beribadah dan penyembahan: "And pray in the Spirit on all occasions with all kinds of prayers and requests.

39 Robert V. McCabe, "Were Old Testament Believers Indwelt by the Spirit?”, Detroit Baptist Seminary Journal, vol. 9, (2004), 217.

${ }^{40}$ Galatian 4:6 menyatakan: "Because you are his sons, God sent the Spirit of his Son into our hearts, the Spirit who calls out, "Abba, Father." 
With this in mind, be alert and always keep on praying for all the Lord's people." (Ephesians 6: 18)

5. Memahami isi kandungan kitab suci iaitu arahan Tuhan (words of God) dengan sebenar-benarnya: "For who knows a person's thoughts except their own spirit within them? In the same way no one knows the thoughts of God except the Spirit of God. What we have received is not the spirit of the world, but the Spirit who is from God, so that we may understand what God has freely given us." (1

Corinthians 2: 11-12)

\section{ii. Kecelaruan Konsep Holy Spirit}

Konsep Holy Spirit sebagai salah satu entiti dalam trinity nyata mengakibatkan banyak permasalahan untuk memahaminya termasuk di kalangan penganut Kristian sendiri. Malahan perbincangan berkenaan Holy Spirit jarang dilakukan secara ilmiah dan menyeluruh berbanding perbincangan mengenai Tuhan Bapa dan Tuhan Anak. Hal ini berlaku disebabkan beberapa faktor, yang pertama; penyataan berkenaan Holy Spirit dalam Bible adalah terhad berbanding Tuhan Bapa dan Tuhan Anak (Jesus). Kedua; keupayaan imaginasi yang kukuh (concrete imagination) untuk menggambarkan konsep ini adalah terhad. Konsep Tuhan Bapa sebagai entiti Tuhan di langit mudah digarap begitu juga Jesus yang dianggap Tuhan yang dihantar ke bumi. Berbeza pula dengan Holy Spirit yang tidak dapat diperjelaskan di mana kedudukannya. Ketiga; masalah untuk menghubungkan ketiga-tiga entiti ini yang boleh memberi gambaran bahawa Holy Spirit berada di kedudukan di bawah Tuhan Bapa dan Jesus. Keadaan (nature) Holy Spirit yang bukan tergolong dalam keduaduanya, namun ia tidak boleh dipisahkan; membuatkan sarjana Kristian menghadapi kesukaran untuk 
membahaskan berkenaannya. ${ }^{41}$ Jefferey E. Brower mengesahkan perkara ini:

"The doctrine of the Trinity poses a deep and difficult problem. On the one hand, it says that there are three distinct Persons-Father, Son, and Holy Spirit - and that each of these Persons "is God". On the other hand, it says that there is one and only one God. So it appears to involve a contradiction. It seems to say that there is exactly one divine being, and also that there is more than one. How are we to make sense of this?" 42

Sarjana Kristian sejak dahulu cuba merungkai persoalan Holy Spirit dalam trinity namun sehingga kini tidak ditemui satu penjelasan yang memuaskan. Pelbagai cara untuk memahami konsep ini telah cuba dikemukakan antaranya menggunakan social analogy, psychological analogy dan the lump-statue analogy. ${ }^{43}$ Namun setelah zaman berzaman kesemuanya diperakui gagal menjawab soal ini secara keseluruhan kerana ianya hanya akan membawa kepada kesimpulan yang buntu. Akhirnya ianya dianggap sebagai 'divine mysteries' yang tidak mungkin dapat difahami oleh manusia. ${ }^{44}$

Konsep Holy Spirit menurut Kristian juga membawa implikasi yang besar dalam keabsahan konsep Tuhan. Seperti mana yang telah dijelaskan penganut Kristian mempercayai bahawa para rasul dalam Kristian

41 Millard. J. Erickson, Christian Theology (Michigan: Baker Book House, 1990), 847.

42 Brower, Logos, 145.

${ }^{43}$ Ketiga-tiga jenis analogi ini merupakan cubaan untuk menggantikan analogi ringkas 'air yang mengambil pelbagai bentuk iaitu cecair, wap dan pepejal' dan 'sebiji telur yang mengandungi telur putih, telur kuning dan kulit' yang tebukti semakin menambahkan kekeliruan kerana analogi 'air' akan membawa kepada faham modalism manakala analogi 'telur' pula akan membawa faham seperatism. Ibid.

${ }^{44}$ Ibid. 
menyampaikan ajaran mereka dengan bantuan dan petunjuk daripada Holy Spirit. Mereka mendakwa teks suci Kristian iaitu Bible yang dipenuhi pelbagai perkara ajaib adalah kebenaran yang tidak pernah diketahui oleh manusia sebelumnya. Oleh itu ianya bukanlah hasil tangan manusia tetapi ianya hasil kerja Holy Spirit. Ia dianggap sebagai kalam Tuhan yang suci, sempurna dan bebas daripada kesilapan. ${ }^{45}$

Namun, banyak kajian ilmiah telah membuktikan bahawa Bible mengandungi pelbagai kesilapan, kesalahan dan percanggahan antara satu penyataan dengan penyataan yang lain, sama ada percanggahan fakta sejarah atau percanggahan usul kepercayaan. ${ }^{46}$ Seandainya ianya dianggap sebagai kalam Tuhan melalui Holy Spirit, percanggahan sedemikian tidak akan berlaku sama sekali. Sekiranya penganut Kristian tetap beranggapan sedemikian, jelaslah bahawa konsep Tuhan menurut mereka adalah Tuhan yang tidak sempurna kerana Tuhan telah melakukan kesalahan. Sebaliknya andai mereka menolak dakwaan ini dengan mengatakan kesilapan itu adalah disebabkan kesalahan manusiawi misalnya kesilapan penterjemahan, jelaslah bahawa Holy Spirit tidak menempati para penulis Bible seperti mana yang didakwa.

\section{Adakah Rūh al-Qudus Sama Dengan Holy Spirit?}

Setelah diamati konsep Rūh al-Qudus dan Holy Spirit, dapat disimpulkan kedua-duanya merujuk kepada entiti yang sama sekali berbeza meskipun menggunakan terma yang serupa. Dalam Islam, Rūh al-Qudus secara jelas merujuk kepada malaikat Jibril, salah satu makhluk Allah SWT yang secara mutlak terpisah daripada zat Tuhan.

${ }^{45}$ R.A. Torrey, The Person and Work of the Holy Spirit as Revealed in the Scriptures and in Personal Experience (Fleming H. Revell Company, 2009), 187.

46 Muḥammad Aḥmad 'Abd al-Qādir al-Malkāwī, Mukhtașar Kitāb Ižnār al-Haqq (Saudi Arabia: Wizārah al-Shu'ūn al-Islāmiyyah wa alAwqāf, 1995). 
Selaku makhluk, Jibril termasuk dalam kalangan hambaNya dan sama sekali tidak mempunyai ciri-ciri ketuhanan. Malaikat Jibril juga menjalankan tugas-tugas yang diamanahkan khususnya menjadi penghubung kepada para nabi dan rasul untuk menyampaikan wahyu Ilahi. Jibril biasanya datang kepada para rasul dengan menjelma dalam bentuk manusia atau bentuk yang mudah diterima oleh manusia dan ada kalanya dalam rupa bentuk sebenar.

Manakala Holy Spirit pula dianggap oleh penganut Kristian sebagai pecahan dari zat Tuhan yang membentuk trinity. Berlainan dengan Rūh al-Qudus, Holy Spirit bukanlah malaikat meskipun ia menjalankan beberapa fungsi yang seakan sama dengan malaikat dalam Islam. Antara perbezaan yang penting untuk digariskan ialah Holy Spirit menempati diri penganut Kristian untuk menjalankan fungsinya ke atas manusia. Ini amat berbeza dengan Rūh alQudus yang tidak menempati diri mana-mana manusia hatta para nabi dan rasul sekali pun. Rüh al-Qudus adalah satu entiti yang berasingan daripada Tuhan dan manusia. Oleh itu jelaslah bahawa Rūh al-Qudus dan Holy Spirit membawa pengertian yang amat berbeza.

Walau bagaimanapun, terdapat beberapa isu Berkenaan Holy Spirit dalam agama Kristian yang boleh dikaitkan dengan konsep Rūh al-Qudus dalam Islam. Dalam beberapa kenyataan Bible, Holy Spirit dikaitkan pula dengan malaikat (angel). Hal ini sedikit sebanyak menyumbang kepada kekeliruan dalam konteks perbandingan Islam-Kristian. Bible merekodkan:

"In all their affliction He was afflicted, and the Angel of His Presence saved them; In His love and in His pity He redeemed them; and He bore them and carried them all the days of old."

(Isaiah 63:9)

Perkataan angel of His Presence di sini bermaksud angel yang paling tinggi, yang paling hebat, yang paling 
dekat dengan Tuhan. Dalam Kristian ianya membawa maksud sama ada Gabriel atau Micheal. Walau bagaimanapun angel of His Presence ini diterjemahkan pula kepada Holy Spirit kerana ayat ini sebenarnya menceritakan berkenaan Holy Spirit. ${ }^{47}$ Maka hal ini akan memberi pemahaman bahawa Holy Spirit ialah termasuk dalam kategori angel sedangkan Holy Spirit bukanlah dari entiti angel sepertimana yang telah dinyatakan.

Dalam sejarah perkembangan ajaran Kristian, ada kelompok yang menolak ketuhanan Holy Spirit dan menganggap ianya adalah malaikat yang tertinggi antaranya kumpulan yang digelar sebagai 'Tropici' ${ }^{48}$ Menurut mereka, Holy Spirit adalah makhluk yang diciptakan daripada tiada menjadi ada (creature brought into existence out of nothingness) dan ianya adalah malaikat yang paling tinggi. ${ }^{49}$ Walau bagaimanapun, pandangan kelompok Tropici ini ditentang oleh Athanasius ${ }^{50}$ yang menganggap pemahaman mereka terhadap teks Bible sebagai menyimpang. Malahan mereka dianggap sebagai kufur (heretic) dan tidak diiktiraf oleh majoriti penganut Kristian. Athanasius menegaskan dengan menolak

${ }^{47}$ Matthew Henry, Commentary.

${ }^{48}$ Tropici merujuk kepada satu kelompok dalam Kristian yang berada di Mesir selepas Persidangan Niccea yang menerima ketuhanan Jesus namun menolak ketuhanan Holy Spirit. Brian LePort, An Introduction to the the Letters to Serapion on the Holy Spirit by Athanasius of Alexandria (Western Seminary, 2010).

${ }^{49}$ Erickson, Christian Theology, 850.

50 St. Athanasius of Alexanderia (293-373) dianggap sebagai tokoh Kristian di Mesir yang melindungi ajaran Kristian daripada 'kekufuran' golongan Arianisme. Beliau turut hadir dalam Persidangan Niccea yang menyaksikan ketuhanan Jesus diiktiraf secara rasmi dalam ajaran Kristian. Encyclopedia Britannicca, dicapai 23 November 2017, https://www.britannica.com/biography/SaintAthanasius. 
ketuhanan holy spirit, ianya bererti menolak ketuhanan Tuhan Bapa itu sendiri. ${ }^{51}$

Dalam Kristian, Rūh al-Qudus merupakan suatu zat yang bersifat ketuhanan (divine) manakala dalam Islam Rūh al-Qudus merujuk kepada malaikat Jibril AS yang sama sekali tidak mempunyai zat Tuhan. Seperti mana yang dijelaskan sebelum ini perkara ini menjadi satu permasalahan yang besar apabila pentafsiran agama masing-masing digunapakai kepada konteks yang sama dalam agama yang berbeza. Hal ini mengakibatkan kekeliruan lebih-lebih lagi dalam masyarakat majmuk yang saling berinteraksi dengan penganut agama lain saban hari. Berkemungkinan juga hal ini menjadi sebab utama isu yang berlaku di Indonesia sepertimana yang berlaku dalam kes Ibu Lia di Indonesia pada 1997.

Apabila pemahaman Rūh al-Qudus (Holy Spirit) menurut Kristian yang dianggap sebagai kesedaran dan roh Tuhan yang mendampingi manusia beriman diaplikasikan dalam pemahaman Rüh al-Qudus dalam Islam akibatnya berlaku kecelaruan dan kekeliruan sehingga 'kesedaran' atau pendamping yang datang itu dianggap sebagai Jibril. Maka, sewajarnya dalam berinteraksi dengan kedua-dua kitab suci iaitu al-Qur'ān dan Bible, perkara ini perlu diperjelaskan untuk mengelakkan berlaku kekeliruan dalam memahami konsep roh suci.

\section{Rumusan}

Konsep roh suci wujud dalam kedua-dua tradisi Islam dan Kristian. Ianya memainkan peranan yang penting dalam pembentukan agama masing-masing. Namun penggunaan istilah yang sama tidak bermaksud ianya membawa pengertian yang serupa. Rūh al-Qudus dalam Islam merujuk kepada Jibril, malaikat yang ditugaskan untuk membawa wahyu kepada para nabi dan rasul. Manakala

${ }^{51}$ C.R.B. Shapland, The Letters of Saint Athanasius Concerning the Holy Spirit (London: The Epworth Press: 1951), 37. 
Holy Spirit pula merujuk kepada salah satu zat Tuhan yang menempati Jesus Christ dan para pengikut Kristian yang 'warak'. Perbezaan ini perlu diperjelaskan untuk mengelakkan sebarang kekeliruan dalam konteks interaksi Islam-Kristian. Ini kerana perbezaan yang wujud bukanlah perkara kecil, bahkan ianya perbezaan yang berkaitan dengan konsep ketuhanan.

\section{Rujukan}

Kishk, Abdul Hamid. The World of Angels. Dār al-Taqwā, t.t.

Adair, James R. Introducing Christianity. Abingdon: Routledge, 2008.

Al-Alūsī, Shihāb al-Dīn al-Sayyid Maḥmūd al-Baghdād̄̄. Rüḥ al-Ma 'ānī fì Tafsīr al-Qur'ān al-Az̄ìm wa al-Sab'i al-Mathānī. Beirut: Dār al-Fikr, 1994.

Al-Aṣfahān̄̄, al-Rāghib. Mufradāt Alfāz al-Qur'ān . Damsyik: Dār al-Qalam, 2009.

Al-Baghawī, Abū Muḥammad al-Husayn bin Mas'ūd. Ma'ālim at-Tanzīl. Riyadh: Dār Tayyibah, 1988.

Brower, Jefferey E. "Understanding the Trinity", Logos: A Journal of Catholic Thought and Culture. jil. 8. no. 1, 2005.

https://www3.nd.edu/ mrea/papers/Understanding\%20t he\%20Trinity.pdf

Al-Burūsawī, Ismā 'îl Haqqī. Tafsīr Rūḥ al-Bayān. Dār alArba'ah 'Uthmaniyyah, t.t.

Erickson, Millard. J. Christian Theology, cet. ke-7. Michigan: Baker Book House. 1990.

Fatwa Dewan Pimpinan Majlis Ulama Indonesia Tentang Malaikat Jibril Mendatangi Manusia, http://mui.or.id/wp-content/uploads/2014/05/09.-FatwaDewan-Pimpinan-MUI-Tentang-Malaikat-JibrilMendamp.pdf.

Flemming, Don. Bridgeway Bible Dictionary, Australia: Bridgeway Publications, 2004. 
Ibn Fāris, Abū al-Ḥusayn Aḥmad. Mu'jam Miqyās alLughah. jil. 2. Damsyik: Dār al-Fikr, 1979.

Ibn Manzūur, Abū Fadhl Jamāl al-Dīn Muhammad bin

Mukram. Lisān al- 'Arab. jil. 2. cet. 1. Beirut: Dār Șādir, 1990.

Ibn Manẓūr, Abū Fadl Jamāl al-Dīn Muhammad bin Mukram. Lisān al- 'Arab. jil. 5. cet. 3. Beirut: Dār Ihyā̄' al-Turāth al-'Arabī, 2012.

Al-Khāzin, Alā 'al-Dīn 'Alì bin Muḥammad bin Ibrāhīm alBaghdādì. Lubab al-Ta'wīl fì Ma 'ànì al-Tanzìl. Beirut: Dār al-Kutub al-'Ilmiyyah, 1995.

LePort, Brian. An Introduction to the the Letters to Serapion on the Holy Spirit by Athanasius of Alexandria. Western Seminary, 2010. https://westernthm.files.wordpress.com/2010/05/leportan-introduction-to-the-letters-to-serapion-on-the-holyspirit-by-athanasius-of-alexandria.pdf.

Al-Malkāwī, Muḥammad Aḥmad 'Abd al-Qādir. Mukhtașar Kitāb Iẓhār al-Haqq. Saudi Arabia: Wizārah al-Shu'ūn al-Islāmiyyah wa al-Awqāf, 1995.

Matthew Henry's Commentary. https://www.biblegateway.com/passage/?search=Matthe $\mathrm{w}+3 \&$ version $=$ NIV \& resource $=$ matthew-henry

McCabe, Robert V. "Were Old Testament Believers Indwelt by the Spirit?" Detroit Baptist Seminary Journal, vol. 9, 2004.

Muhammad Fu'ād Abd al-Bāqī. Al-Mu'jam al-Mufahris li Alfāz al-Qur'ān al-Karīm. Kaherah: Dār al-Hadis, 1996. Mustafā 'Āshūr. 'Ālam al-Malā'ikah Asrāruh wa Khafāyāh. Kaherah: Maktabah al-Qur'ān, t.t.

New American Bible (Revised Edition) (NABRE). Washington DC: Confraternity of Christian Doctrine Inc. 2011, https://www.biblegateway.com.

Pereira, Marry Ellen. "The Holy Spirit In The Gospel Of John", Leaven: Vol. 12: Iss. 3, Article 5, 2004. 
Al-Rāzī, Fakhr al-Dīn. Tafsīr al-Kabīr wa Mafātih alGhayb, jil. 3. Beirut: Dār al-Fikr, 1981.

Schaff, Philip. History of the Christian Church Volume III:

Nicene and Post-Nicene Christianity. A.D. 311-600. Michigan: Christian Classic Ethereal Library, t.t. (http://www.ccel.org/s/schaff/hcc3/cache/hcc3.pdf)

Shapland, C. R. B. The Letters of Saint Athanasius Concerning the Holy Spirit. London: The Epworth Press, 1951.

Shih-Ching, Judy Tao. “The Holy Spirit In The Qur'an: An Assessment From A Christian Perspective". (Disertasi Sarjana University of Stellenbosch, South Africa), 2006. Al-Suyūțí, Jalāl al-Dīn. Al-Durr al-Manthūr fì al-Tafsīr bi al-Ma'thūr, jil. 1. Kaherah: Markaz Hajr li al-Buhūth wa al-Dirāsāt al-'Arabiyyah wa al-Islāmiyyah, 2003.

Torrey, R.A. The Person and Work of the Holy Spirit as Revealed in the Scriptures and in Personal Experience. Fleming H. Revell Company, 2009.

Vines, V.E. Vine's Complete Expository Dictionary of Old and New Testament Words, t.t.

Al-Zamakhsharī, Abū al-Qāsim Maḥmūd bin 'Umar. AlKashshāf 'an Haqū'iq al-Tanzīl wa 'Uyūn al-Aqāwil fī Wujūh al-Ta'wīl. Beirut: Dār al-Ma 'rifah, 2009. 
Adam Badrulhisham \& Khadijah, "Konsep Roh Suci menurut Islam dan Kristian," Afkār Vol. 20 Issue 1 (2018): 85-108 